Chinese Journal of Organic Chemistry

\title{
过渡金属催化的不对称电化学进展
}

\author{
王向阳 ${ }^{a}$ 徐学涛 ${ }^{a}$ 王振华 $b$ 方 萍 $*, b \quad$ 梅天胜 $*, b$ \\ ( ${ }^{a}$ 五邑大学生物科技与大健康学院 广东江门 529020) \\ $\left({ }^{b}\right.$ 中国科学院上海有机化学研究所 金属有机化学国家重点实验室 分子合成科学卓越中心 上海 200032)
}

\begin{abstract}
摘要 总结了近年来过渡金属催化的不对称电化学进展. 过渡金属催化的不对称电化学(AOMCE)分为氧化和还原反 应. 在氧化反应方面, 发展了烯烃的不对称官能团化, 二级醇或醛的动力学拆分以及碳氢键的不对称官能团化反应. 在还原反应部分包括二氧化碳的不对称电化学羧化、不对称电化学脱羒反应以及不对称还原偶联反应. 手性配体和过 渡金属催化剂与电化学体系的结合构成了一个非常新颖的反应体系, 为解决传统有机电化学合成中立体选择性控制的 难题, 提供了一条新途径.

关键词＼cjkstart过渡金属催化的不对称电化学; 有机电化学合成; 不对称催化
\end{abstract}

\section{Advances in Asymmetric Organotransition Metal-Catalyzed Electrochemistry}

\author{
Wang, Xiangyang ${ }^{a} \quad \mathrm{Xu}_{\text {, Xuetao }}{ }^{a} \quad$ Wang, Zhenhua $^{b} \quad$ Fang, Ping $^{*, b} \quad$ Mei, Tiansheng ${ }^{*, b}$ \\ ( ${ }^{a}$ School of Biotechnology and Health Science, Wuyi University, Jiangmen, Guangzhou 529020) \\ $\left({ }^{b}\right.$ State Key Laboratory of Organometallic Chemistry, Center for Excellence in Molecular Synthesis, \\ Shanghai Institute of Organic Chemistry, Chinese Academy of Sciences, Shanghai 200032)
}

\begin{abstract}
The recent developments in asymmetric organotransition metal-catalyzed electrochemistry (AOMCE) are summarized. AOMCE processes can be divided into oxidative and reductive variants. In terms of oxidations, asymmetric functionalization of olefins, oxidative kinetic resolution of secondary alcohols or aldehydes, and asymmetric $\mathrm{C}-\mathrm{H}$ functionalization reactions have been developed. Reductive processes discussed include asymmetric electrochemical carboxylation with carbon dioxide, asymmetric electrochemical decarboxylation, and asymmetric reductive coupling reactions. The combination of chiral ligands, transition-metal catalysts, and electrochemistry provides a novel angle by which to address the longstanding fundamental challenge of stereoinduction in traditional electrochemical organic synthesis.

Keywords asymmetric organotransition metal-catalyzed electrochemistry; electrochemical organic synthesis; asymmetric catalysis
\end{abstract}

\section{Introduction}

Kolbe $^{[1]}$ and Baizer ${ }^{[2]}$ successful introduced electricity into organic synthesis by dimerizing carboxylic acids (in 1847) and acrylonitrile (in 1964), respectively. In recent decades, electrochemistry has made tremendous advances as a platform for the discovery of novel synthetic transformations. ${ }^{[3]}$ Through electrochemistry, challenging transformations are made possible by the ability to generate free radical intermediates under mild conditions. ${ }^{[4]}$ At the same time, controlling chemoselectivity, regioselectivity, and stereoselectivity of a given electrochemical transformation can be difficult, particularly converting achiral compounds into chiral ones.

Significant effort has been made to develop efficient enantioselective electrochemical protocols, ${ }^{[5]}$ including via the use of chiral solvents, ${ }^{[6]}$ chiral auxiliaries, ${ }^{[7]}$ chiral supporting electrolytes, ${ }^{[8]}$ chiral mediators, ${ }^{[9]}$ chiral elec-

\footnotetext{
* Corresponding authors. E-mail: mei7900@sioc.ac.cn; pfang@sioc.ac.cn Received March 9, 2020; revised May 24, 2020; published online May 25, 2020.

Dedicated to the 40th anniversary of Chinese Journal of Organic Chemistry.

Project supported by the Strategic Priority Research Program of the Chinese Academy of Sciences (No. XDB20000000), the National Natural Science Foundation of China (Nos. 91956112, 21572245, 21772222, 21772220), and the Program of Shanghai Science and Technology Committee of Shanghai (Nos 17JC1401200, 18JC1415600).

中国科学院战略性先导科技专项(No. XDB20000000)、国家自然科学基金(Nos. 91956112, 21572245, 21772222, 21772220)和上海市科委基础研究(Nos. $17 \mathrm{JC} 1401200,18 \mathrm{JC} 1415600)$ 资助项目.
} 
trodes, ${ }^{[10]}$ or chiral catalysts. ${ }^{[5,11]}$

Organotransition-metal catalysts provide a particular promising means to realizing high chemoselectivity, regioselectivity, and stereoselectivity within an electrochemical process. Three specific advantages of an organotransition metal-catalyzed approach are: (1) the redox potential of the transition-metal catalyst may be tuned by changing substituents on the ligand, (2) modification of the ligand can dictate the reaction stereoselectivity (and chemoselectivity and regioselectivity), (3) well-established thermochemical organotransition metal-catalyzed methodologies provide a rigorous foundation for the development of electrochemical variants.

In this review, we emphasize the recent advances in asymmetric organotransition metal-catalyzed electrochemistry (AOMCE), which we defined as reactions that require the combination of transition-metal catalyst, chiral ligand, and electricity. AOMCE can be divided into two types: asymmetric electrochemical oxidation and asymmetric electrochemical reduction. In the asymmetric electrochemical oxidation section, olefin functionalization, kinetic resolution of secondary alcohols or aldehydes, and $\mathrm{C}-\mathrm{H}$ functionalization are discussed. In the reductive section, asymmetric electroreductive carboxylation with carbon dioxide, electrochemical decarboxylation, and reductive couplings are highlighted.

\section{Asymmetric organotransition metal- catalyzed electrochemical oxidation}

\subsection{Asymmetric electrochemical oxidative function-} alization of olefins

The osmium tetroxide-catalyzed oxidation of olefins to produce vicinal diols is a well-known and reliable synthetic method in organic chemistry. ${ }^{[12]}$ Due to the high cost and toxicity of osmium, it is employed catalytically for alkene oxidations in the presence of a less expensive and toxic terminal oxidant. ${ }^{[13]}$

In 1992, Amundsen and co-workers ${ }^{[14]}$ reported the synthesis of a number of chiral diols using a modification of the Sharpless process in an electrolytically regenerated system (Scheme 1a). Osmium tetroxide bearing chiral ligand L1 (hydroquinidine 4-chlorobenzoate) was employed as catalyst, and a catalytic amount of potassium ferricyanide was used as mediating oxidant. A divided cell was necessary to prevent cathodic reduction of ferricyanide oxidant and electrodeposition of osmium. Enantiomeric selectivity was predicated on having bulky alkene substituents, namely phenyls. $^{[15]}$

In 1995, Torii and co-workers ${ }^{[16]}$ improved the process of asymmetric electrodihydroxylation of olefins under constant current in an undivided cell using dihydroquinidine phthalazine ligand L2 and less osmate catalyst and potassium ferricyanide (Scheme 1b). A year later Torii and co-workers ${ }^{[17]}$ developed a variant employing iodine as an oxidizing mediator (Scheme 1c). The desired diols were obtained in high ee values and high yields in each of these optimized processes.

Optically active epoxides are versatile intermediates in the synthesis of pharmaceuticals, agrochemicals, and functional materials. ${ }^{[18]}$ Electrochemical asymmetric epoxidation has been investigated as an alternative process avoiding the use of a stoichiometric amount of co-oxidant. ${ }^{[19]}$ In 2001, Tanaka and co-workers ${ }^{[20]}$ reported an efficient enantioselective $\mathrm{Mn}$ (salen)-catalyzed electro-epoxidation of olefins in a two-phase $\mathrm{CH}_{2} \mathrm{Cl}_{2} / \mathrm{NaCl}$ (aq.) electrolysis system in an undivided cell (Scheme 2a). The electro-epoxidation of indene $\mathbf{3 e}$ gave the corresponding epoxide $\mathbf{4 e}$ in rather low yield and enantioselectivity. Due to the high reactivity of the double bond, which enabled undesired oxidations by an electro-generated chlorine species $\left[\mathrm{Cl}^{+}\right]$.

The $\mathrm{CH}_{2} \mathrm{Cl}_{2} /$ water two-phase system played an important role in the reaction. When using water-miscible organic solvents, such as $t$ - $\mathrm{BuOH}$ and $\mathrm{MeCN}$, a complex mixture of unidentified products was formed in lieu of the desired epoxide, possibly a result of decomposition of $\mathrm{Mn}$ (salen) via oxidation at the anode. In the two-phase system, electrochemical oxidation occurs only in the aqueous phase, thereby suppressing direct electrochemical oxidation of $\mathrm{Mn}$ (salen) which resides in the organic phase. A plausible mechanism is presented in Scheme $2 b$.

Recently, Lin and co-workers ${ }^{[21]}$ reported the development of highly enantioselective cyanophosphinoylations or cyanosulfinylations of alkenes using rational ligand design and optimization of the electrolysis conditions (Scheme 3a). Substantial modification of the ligand scaffold was required to break a selectivity ceiling that they encountered. Introduction of an ancillary ligand to the BOX (bisoxazolines) scaffold (specifically an ester group) was used to further stabilize the putative pentacoordinated $\mathrm{Cu}(\mathrm{III})$ complex prior to reductive elimination. This modification also served to increase the rigidity of the transition state and improve the stereochemical fidelity of the cyanation process (Scheme 3b). Moreover, Lin and co-workers hypothesized that the multidentate ligand further stabilized the $\mathrm{Cu}$ catalyst against cathodic demetallation and present a cationic intermediate (I, Scheme $3 \mathrm{~b}$ ) that was more susceptible to reductive elimination.

\subsection{Kinetic resolution via electrochemical oxidation}

Selective oxidation of hydroxyl groups into carbonyl groups is an important organic transformation. In 2008, Onomura and co-workers ${ }^{[22]}$ reported a copper-catalyzed electrochemical oxidation kinetic resolution of racemic cis-cycloalkane-1,2-diols, aminoalcohols, and aminoaldehydes. Their efficient procedure employed copper(II) triflate and $(R, R)$-Ph-BOX ligand with tetraethylammonium bromide as the oxidizing mediator (Scheme 4). The method was applicable to the kinetic resolution of some piperidine-3,4-diols (rac-10 and rac-12, Schemes $4 \mathrm{~b}$ and $4 \mathrm{c}$ respectively). It bears mentioning that these substrates are not efficiently oxidized by NBS ( $N$-Bromosuccinimide). ${ }^{[23]}$

\subsection{Asymmetric $\mathrm{C}-\mathrm{H}$ functionalization}

In 1975, Shono and co-workers ${ }^{[25]}$ demonstrated an an- 
(a)
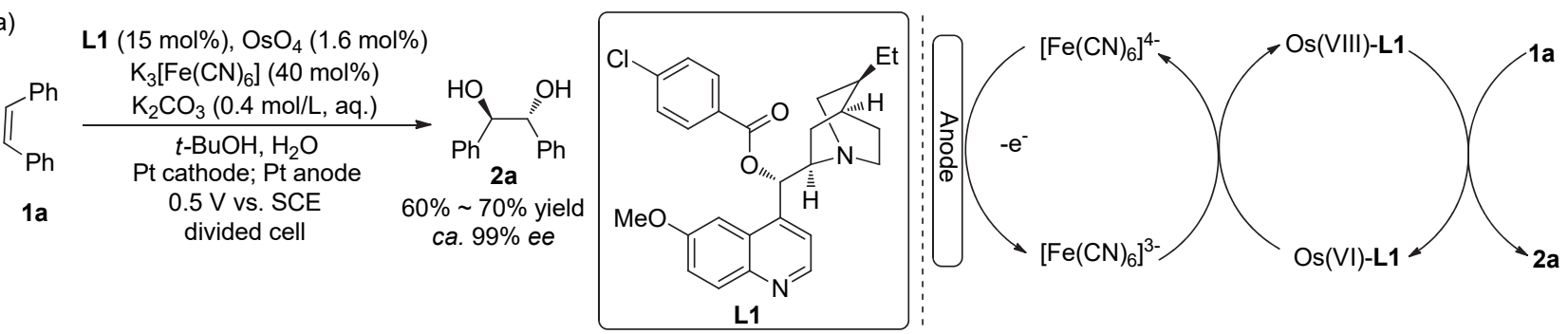

(b)
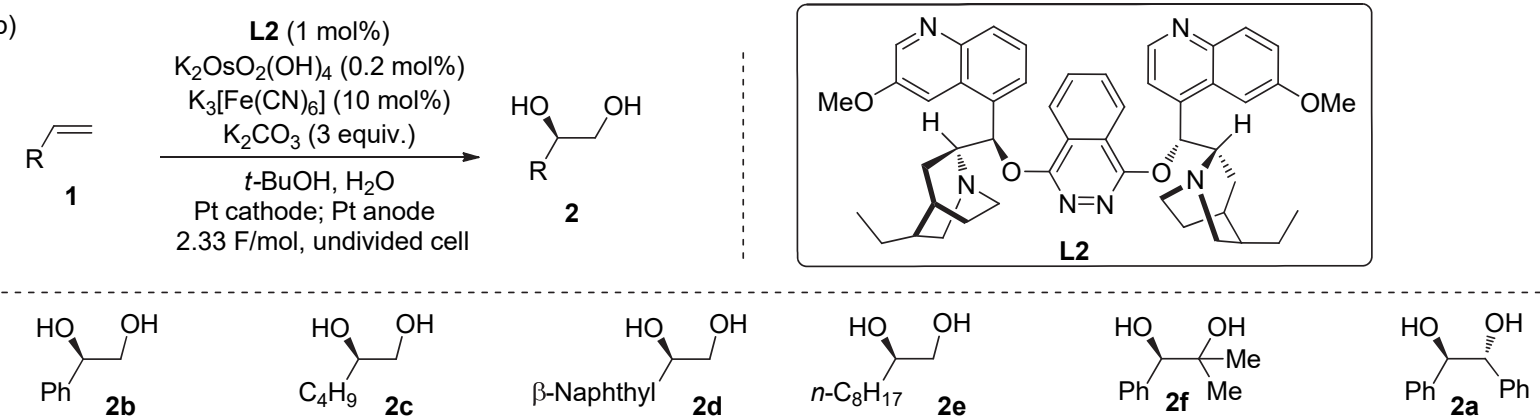

$95 \%$ yield, $97 \%$ ee

$71 \%$ yield, $84 \%$ ee

$87 \%$ yield, $86 \%$ ee

(c)

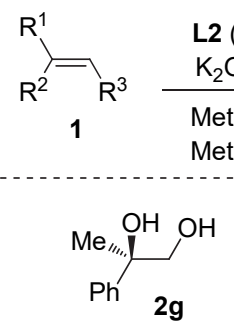

$69 \%$ yield, $92 \%$ ee

$93 \%$ yield, $90 \%$ ee

$97 \%$ yield, $100 \%$ ee

$$
t \text { - } \mathrm{BuOH}
$$

Pt cathode; Pt anode $5.11 \mathrm{~F} / \mathrm{mol}$, undivided cell

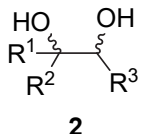

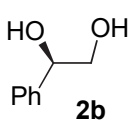

Method A: $94 \%$ yield, $98 \%$ ee $99 \%$ yield, $96 \%$ ee $95 \%$ yield, $97 \%$ ee Method B: $96 \%$ yield, $97 \%$ ee $93 \%$ yield, $94 \%$ ee $89 \%$ yield, $97 \%$ ee

$$
\text { Naphthyl } \underbrace{\mathrm{OH}}_{2 \mathbf{i}} \mathrm{OH}
$$
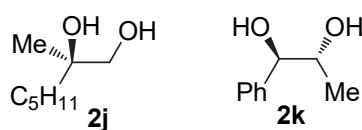

Method A: $85 \%$ yield, $>99 \%$ ee $89 \%$ yield, $96 \%$ ee $84 \%$ yield, $99 \%$ ee Method B: $89 \%$ yield, $>99 \%$ ee $92 \%$ yield, $96 \%$ ee $93 \%$ yield, $97 \%$ ee

Scheme 1 Os-catalyzed asymmetric electrochemical dihydroxylation of olefins

(a)

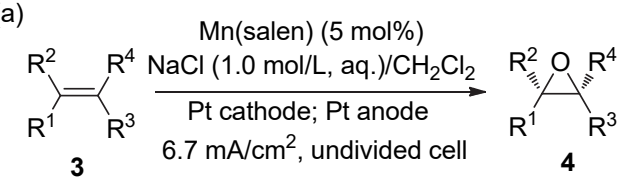<smiles>CC1OC1c1ccccc1</smiles>

$93 \%$ yield, $87 \%$ ee<smiles>c1ccc2c(c1)CCC1OC21</smiles>

4d

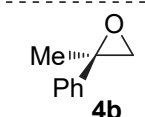

$4 \mathrm{~b}$
$69 \%$ yield, $43 \%$ ee

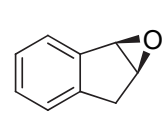

4 e

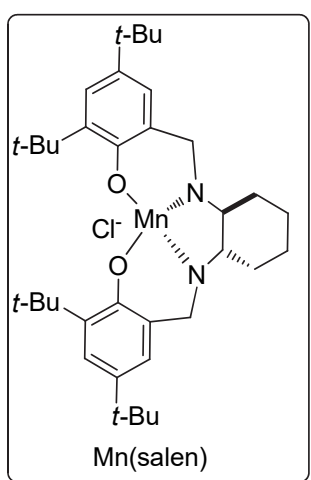

(b) A plausible mechanism
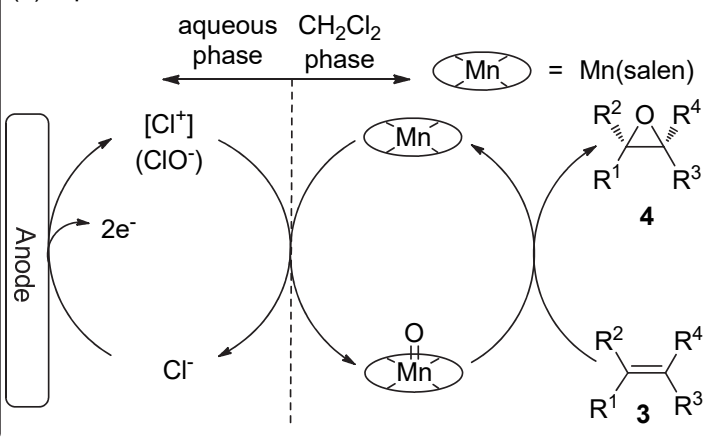

$47 \%$ yield, $70 \%$ ee

$30 \%$ yield, $26 \%$ ee

Scheme 2 Mn-salen-catalyzed asymmetric electrochemical epoxidation of olefins

odic oxidation of carbamates to $N$-carbamoyl iminium ions. ${ }^{[24]}$ The resulting $N$-carbamoyl iminium ions can be trapped with various nucleophiles, including allyl silanes, cyanide, fluoride, furans, and isocyanides. This provided a powerful tool for the $\alpha-\mathrm{C}-\mathrm{H}$ functionalization of amines. ${ }^{[26]}$ Early attempts at asymmetric Shono-type oxidative cross-couplings relied on chiral auxiliaries and afforded varying levels of stereoselectivity when using alkyl nucleophiles. ${ }^{[27]}$ In 2017, Luo and coworkers ${ }^{[28]}$ developed a protocol using enamine catalysis and electrochemical $\mathrm{C}-\mathrm{H}$ oxidation, providing $\mathrm{C} 1$-alkylated tetrahydroisoquinolines (THIQs) in good-to-excellent diastereoselectivity and enantioselectivity.

Very recently, Mei and co-workers ${ }^{[29]}$ reported the first example of $\mathrm{Cu}$ /TEMPO (2,2,6,6-tetramethylpiperidinyl$\mathrm{N}$-oxyl) co-catalyzed electrochemical enantioselective oxidative cross-coupling between cyclic tertiary amines and terminal alkynes using a novel chiral bisoxazoline ligand in an undivided cell (Scheme 5a). The reaction exhibited high enantioselectivity and broad functional group tolerance. 


$$
\begin{aligned}
& \text { (a) }
\end{aligned}
$$

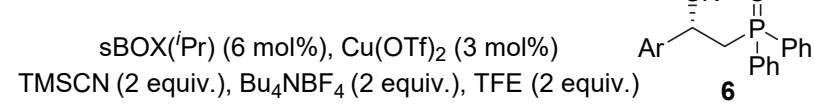

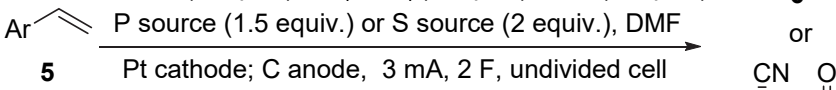

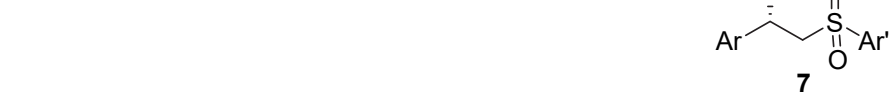

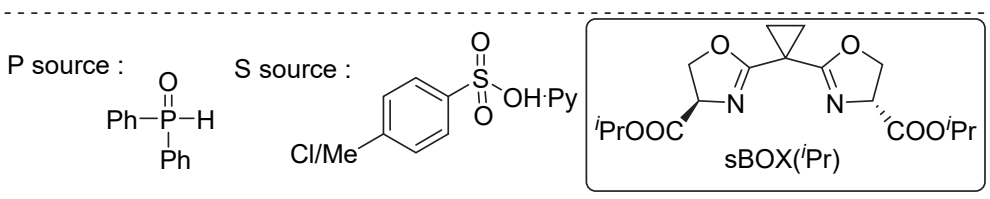

(b) Rational ligand modification: introducing second-sphere functional groups

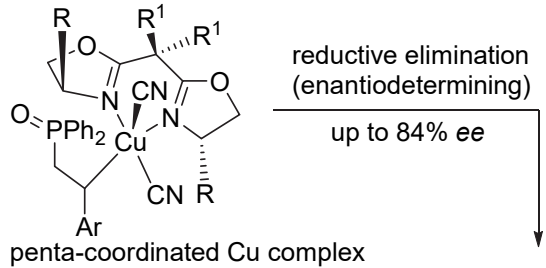
penta-coordinated Cu complex

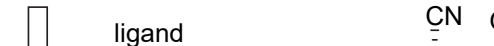<smiles>N#C[C@H]([Al])CP(=O)(c1ccccc1)c1ccccc1</smiles>

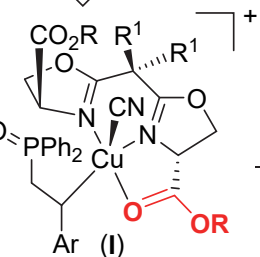<smiles>N#C[C@@H](CP(=O)(c1ccccc1)c1ccccc1)c1ccccc1</smiles>

$63 \%$ yield, $88 \%$ ee<smiles>[3H]C[C@H](C#N)c1ccc(OC)nc1</smiles>

$82 \%$ yield, $89 \%$ ee<smiles>N#CC(CP(=O)(c1ccccc1)c1ccccc1)c1cccc(C=O)c1</smiles>

$55 \%$ yield, $90 \%$ ee<smiles>Cc1ccc(CC(C#N)P(=O)(c2ccccc2)c2ccccc2)cc1</smiles>

$75 \%$ yield, $93 \%$ ee<smiles>[3H]C[C@@H](C#N)c1ccc2c(ccn2[3H])c1</smiles>

$69 \%$ yield, $93 \%$ ee

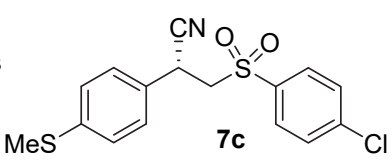

$65 \%$ yield, $98 \%$ ee
Scheme 3 Cu-catalyzed asymmetric electro-cyanophosphinoylation or -cyanosulfinylation of alkenes

(a)

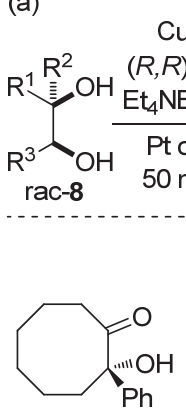

9 a

$49 \%$ yield $80 \%$ ee
$\mathrm{Cu}(\mathrm{OTf})_{2}(10 \mathrm{~mol} \%)$ R,R)-Ph-BOX (10 mol\%)

cathode; Pt anode ${ }_{4} \mathrm{NBr}$ ( 1.0 equiv.), $\mathrm{MeOH}$

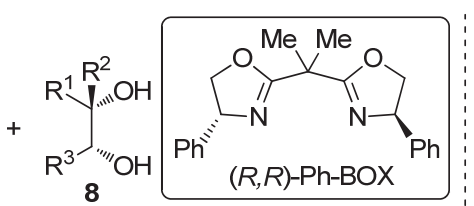

(b) (c) up to $95 \%$ ee

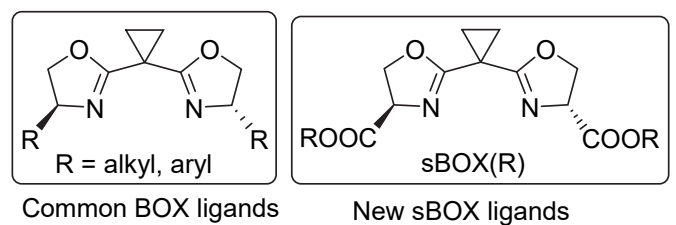

Common BOX ligands

New sBOX ligands
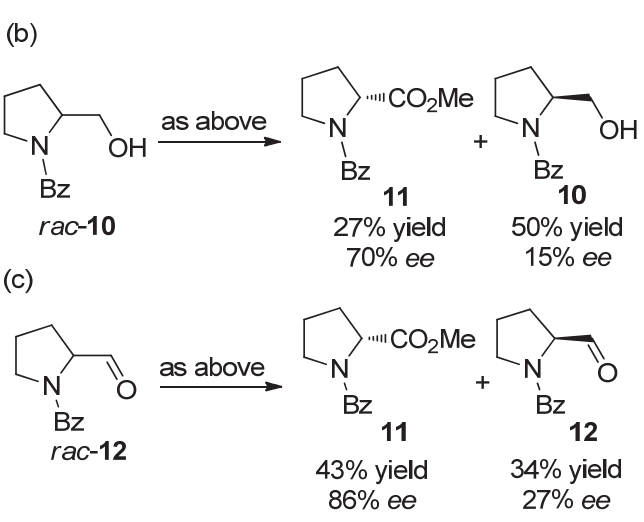

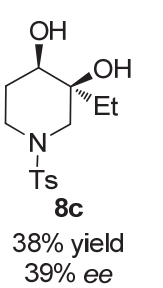

The use of TEMPO as a co-catalytic redox mediator was crucial not only for oxidizing a tetrahydroisoquinoline to an iminium ion species, but also for dimishing the oxidation potential of the reaction. A plausible catalytic cycle is shown in Scheme 5b. First, oxoammonium species $\left(\mathrm{TEMPO}^{+}\right) \mathbf{1 7}$ is formed via anodic oxidation of TEMPO. Upon hydride transfer, ${ }^{[30]}$ iminium intermediate 20 is generated from 13, with the concomitant formation of TEMPO-H 16, which can be converted into 17 by anodic oxidation. Addition of the chiral acetylide species 19 (derived from $\mathrm{Cu}(\mathrm{I})$ and alkyne $\mathbf{1 4}$ in the presence of base) to electrophilic 18 results in the formation of product 15. Active $\mathrm{Cu}(\mathrm{I})$ could be generated by either the reaction of $\mathrm{Cu}(\mathrm{II})$ with TEMPO-H, or cathodic reduction of $\mathrm{Cu}(\mathrm{II}) .{ }^{[31]}$ Alternatively, other cooperative modes involving both $\mathrm{Cu}$ (II) and TEMPO in the key oxidative iminium-formation step could not be ruled out. ${ }^{[32]}$
In 2019, Meggers and co-workers ${ }^{[33]}$ reported an electricity-driven asymmetric $\Delta$-Rh-catalyzed oxidative crosscoupling of 2-acyl imidazoles with silyl enol ethers for the generation of enantioenriched 1,4-dicarbonyls in high yield and high enantionselectivity, including access to quaternary stereocenters (Scheme 6a). The reaction exhibited broad functional group tolerance. The chiral Lewis acid catalyst $\Delta$-Rh was shown to be involved in both the electrochemical step and the asymmetric induction. Substrate binding to the catalyst and subsequent deprotonation raised the highest occupied molecular orbital and triggered a mild and selective anodic oxidation to provide a catalyst-bound reactive intermediate that engaged in a stereo-controlled radical $\mathrm{C}$ $\mathrm{C}$ bond-forming reaction. A plausible mechanism is shown in (Scheme 6b). Later in 2019, Guo and co-workers ${ }^{[34]}$ reported a Ni-catalyzed asymmetric electrochemical alkylation via benzylic $\mathrm{C}-\mathrm{H}$ bond functionalization (Scheme 7a). 
(a)
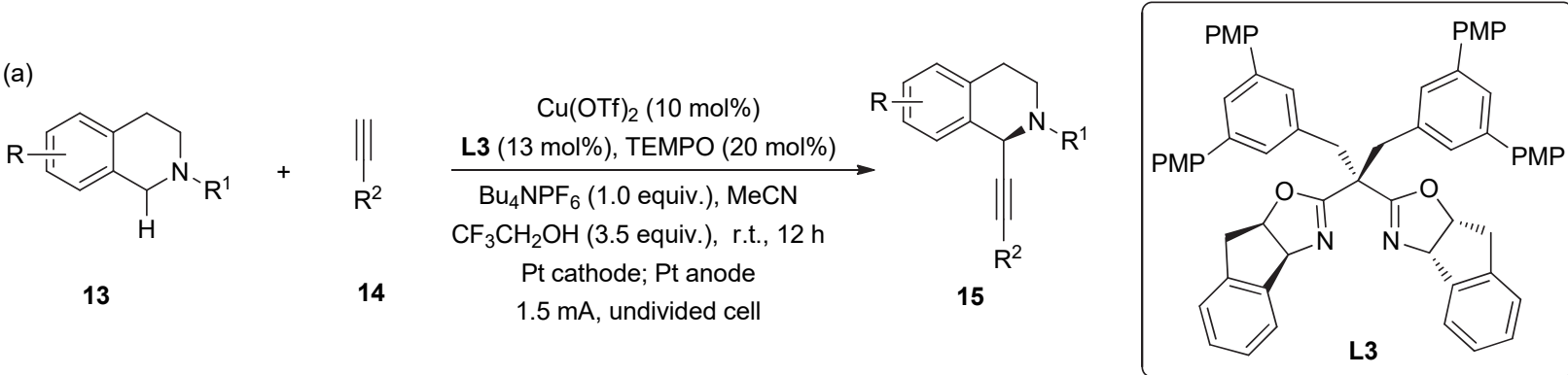

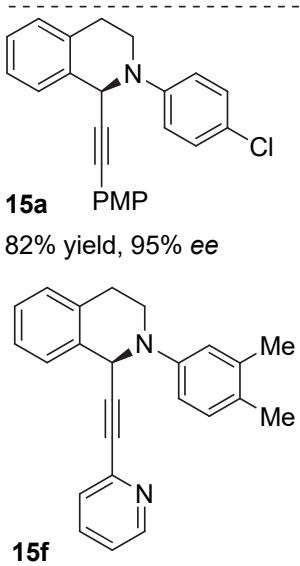

$63 \%$ yield, $90 \%$ ee

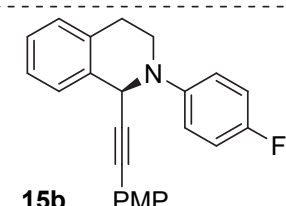

15b PMP

$76 \%$ yield, $97 \%$ ee

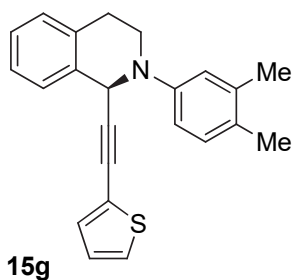

$63 \%$ yield, $95 \%$ ee

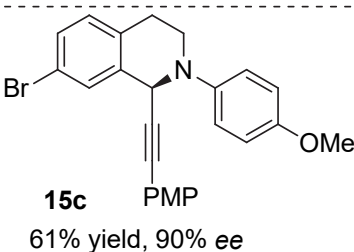

$73 \%$ yield, $94 \%$ ee

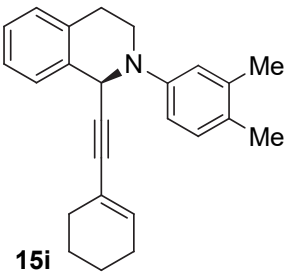

$68 \%$ yield, $90 \%$ ee

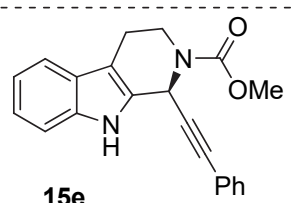

$27 \%$ yield, $92 \%$ ee

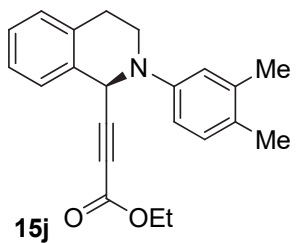

$37 \%$ yield, $86 \%$ ee

(b) Plausible catalytic cycle

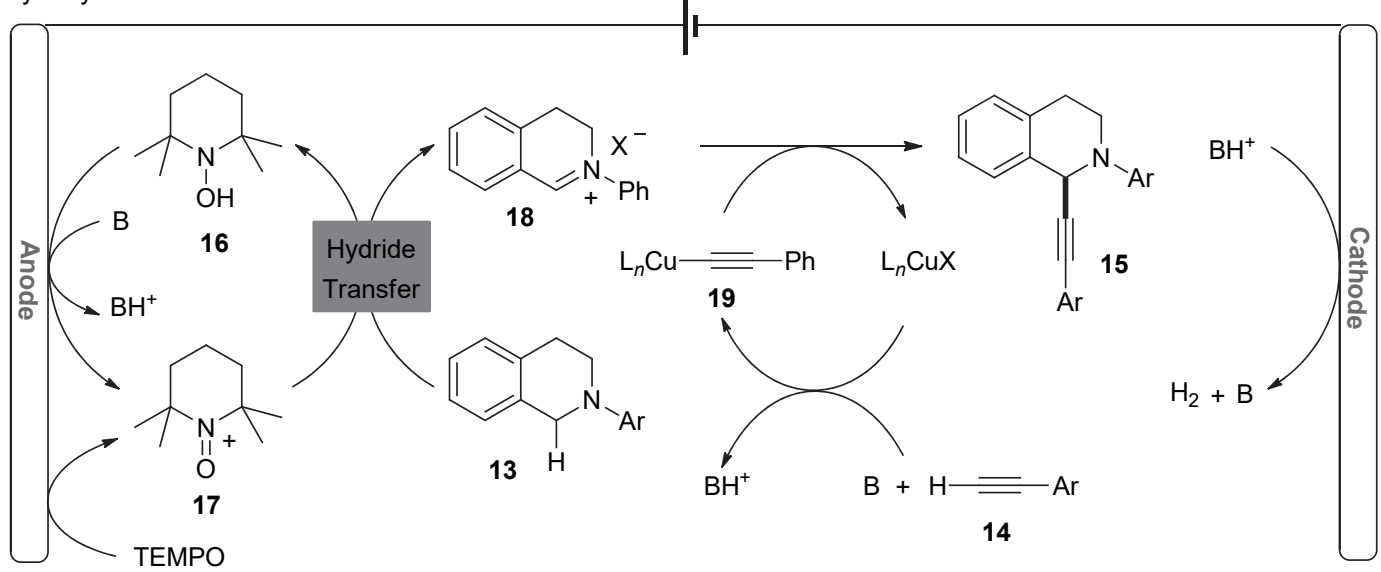

Scheme 5 Cu-catalyzed enantioselective $\mathrm{C}-\mathrm{H}$ alkynylation via Shono-type oxidation

The imidazole protecting group in substrate $\mathbf{2 3}$ proved crucial for the transformation, as there was no alkylation product with other protecting groups. The electrochemical alkylation products were then applied to the synthesis of target compound 26, which has antibacterial activity (Scheme $7 b){ }^{[35]}$ The proposed mechanism of the reaction is depicted in Scheme 7c. First, the coordination of Ni-catalyst to substrate $\mathbf{2 3}$ affords intermediate $\mathbf{F}$, which is deprotonated to afford $\mathbf{G}$. Intermediate $\mathbf{G}$ is then oxidized at the anode to form the radical intermediate $\mathbf{H}$, which cross-coupled to electrochemically generated benzylic radical $\mathbf{J}$ to afford the alkylation product $\mathbf{2 5}$.

Very recently, Ackermann and co-workers published the first electrochemical enantioselective synthesis of axially-chiral biaryls, which used a catalytic amount of transient directing group (TDG) in Pd-catalyzed asymmetric electrochemical $\mathrm{C}-\mathrm{H}$ olefinations. This protocol afforded highly enantiomerically-enriched biaryls and axially chiral $\mathrm{C}-\mathrm{N}$ bond scaffolds that the authors showed could be used to expediently access to novel enantio-enriched helicenes, dicarboxylic acids, and 1,1'-Binaphthalene-2,2'-diyl)bis(diphenylphosphine) (BINOLs) (Scheme 8). ${ }^{[36]}$

\section{Asymmetric organotransition metal- catalyzed electrochemical reduction}

\subsection{Asymmetric electroreductive carboxylation with carbon dioxide}

Catalytic carbon-carbon $(\mathrm{C}-\mathrm{C})$ bond-forming reactions that utilize carbon dioxide $\left(\mathrm{CO}_{2}\right)$ to directly access carbox- 
(a) $0 \quad \Delta$ - Rh $(5 \mathrm{~mol} \%)$

(a) $\begin{array}{ccc}20 & 21 & 2.0 \sim 2.4 \mathrm{~F} / \mathrm{mol} \text {, undivided cell }\end{array}$<smiles></smiles>
$\mathrm{Ph}{ }^{\mathrm{COPh}}$

22a

$80 \%$ yield, $96 \%$ ee<smiles>C=C(C[C@H](C(=O)c1nccn1-c1ccccc1)C1=CCCCC1)C1CCCCC1</smiles>

$$
\text { 22b } 0
$$

$82 \%$ yield, $95 \%$ ee<smiles>O=C(C[C@@H](C(=O)c1ccccc1)c1ccsc1)Oc1ccccc1</smiles>
$22 \mathrm{c}$<smiles>O=C(/C=C/c1ccccc1)CC(C(=O)c1nccn1-c1ccccc1)c1ccccc1</smiles>
22d $\mathrm{O}$ $42 \%$ yield, $98 \%$ ee $\quad 77 \%$ yield, $96 \%$ ee<smiles>C#CCCC[C@](CC(=O)Oc1ccccc1)(C(=O)OC)C(=O)c1nccn1C</smiles>
$\mathrm{Me} \mathrm{COPh}$

$83 \%$ yield, $96 \%$ ee $\quad 69 \%$ yield, $96 \%$ ee $\quad 69 \%$ yield, $90 \%$ ee

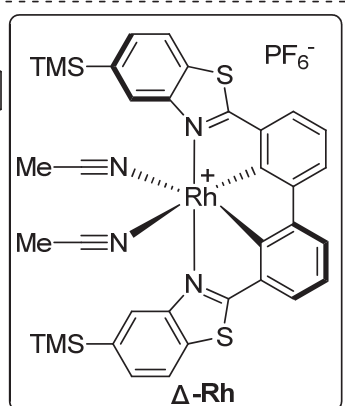

$\Delta-R h$ (b) A plausible mechanism

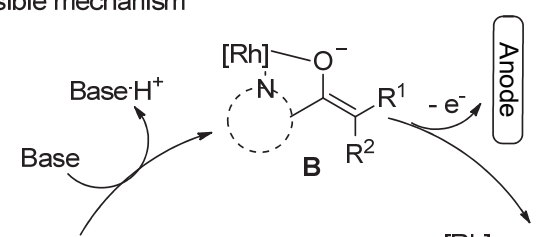

$[\mathrm{Rh}]-\mathrm{O}$

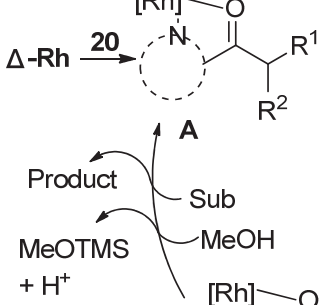<smiles>C1C2CN1C2</smiles><smiles>[R17]C(=C)C(CNCC)C(=C)C</smiles><smiles>[R]C1CCCCC1</smiles>

Cathode $2 \mathrm{H}^{+}+2 \mathrm{e}^{-} \longrightarrow \mathrm{H}_{2}$

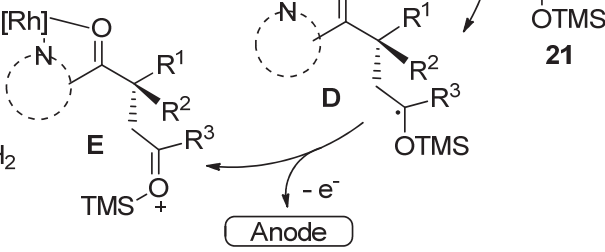

Scheme 6 Rh-catalyzed electro-oxidative cross-coupling

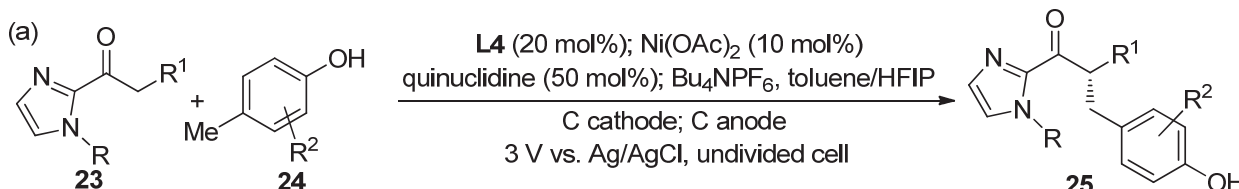

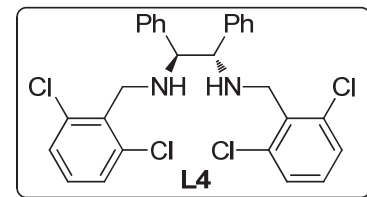<smiles>CCn1ccnc1C(=O)[C@@H](Cc1cc(C)c(O)c([N+](=O)[O-])c1)c1ccccc1</smiles>

$82 \%$ yield, $94 \%$ ee

(b) Synthesis application

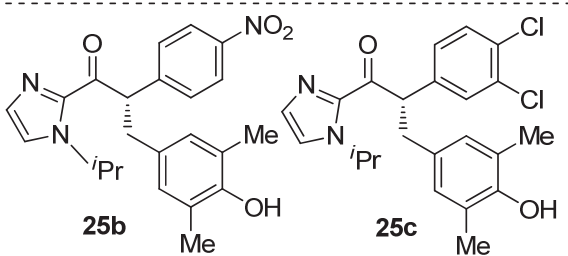<smiles>Cc1cc(C[C@H](C(=O)c2nccn2-c2ccccc2)c2ccccc2)cc(C)c1O</smiles><smiles>CCCn1ccnc1C(=O)C(Cc1cc(-c2ccc(OC)cc2)c(O)c([N+](=O)[O-])c1)c1ccccc1</smiles>
$79 \%$ yield, $87 \%$ ee $\quad 79 \%$ yield, $89 \%$ ee

$61 \%$ yield, $94 \%$ ee
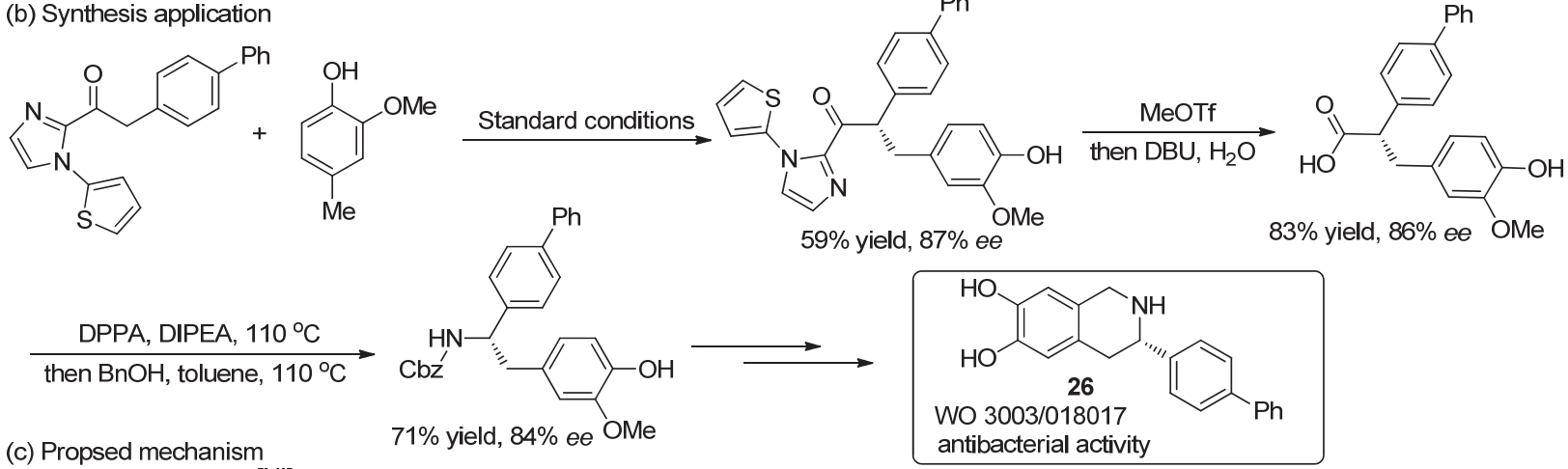

(c) Propsed mechanism

$71 \%$ yield, $84 \%$ ee OMe

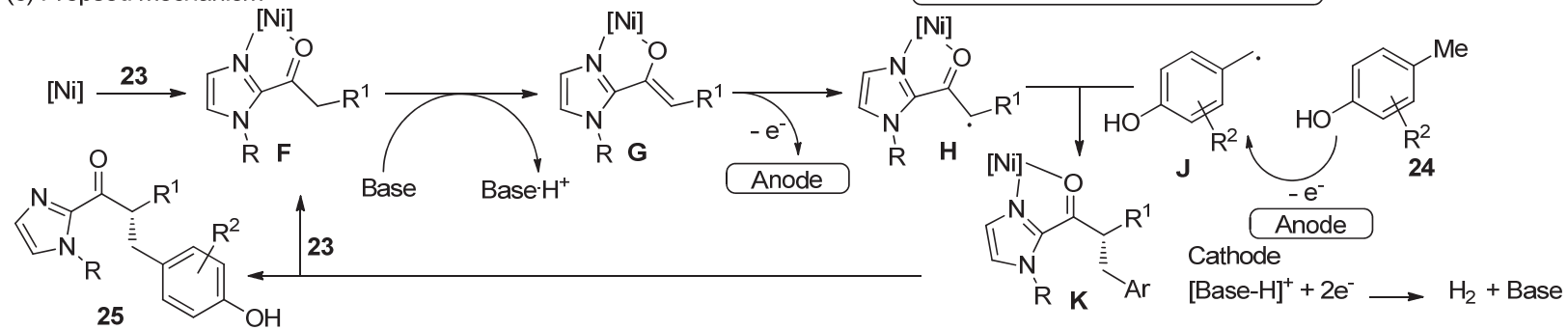

Scheme 7 Ni-catalyzed asymmetric electrochemical alkylation 


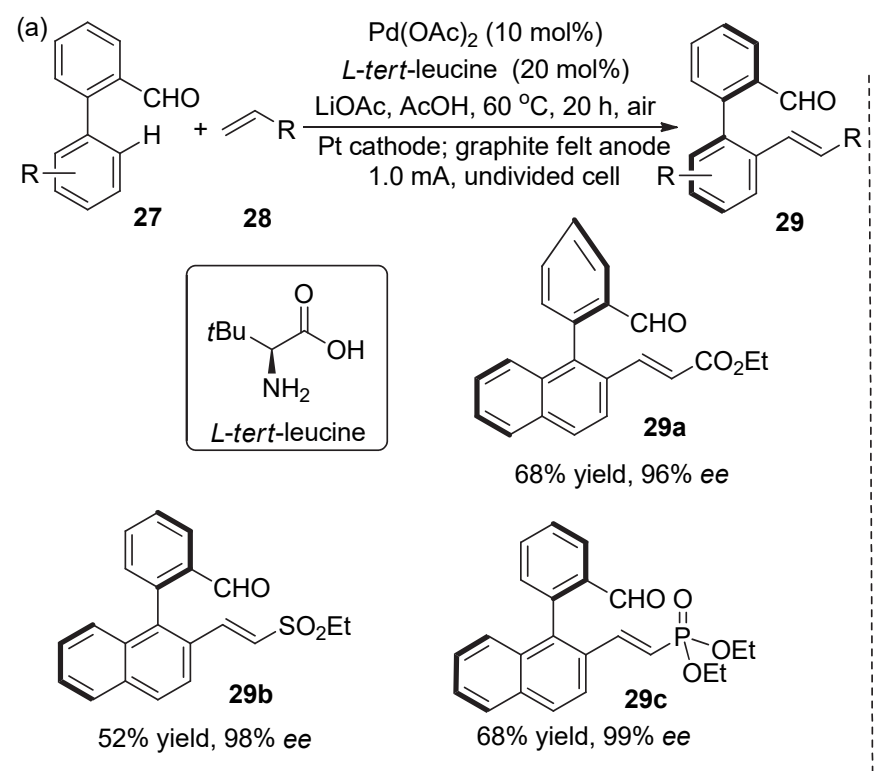
(b)<smiles>CCOC(=O)/C=C/C1=C(n2cccc2C=O)C2=CC=CC=C(C=C1)c1cccn12</smiles>

$56 \%$ yield, $98 \%$ ee $\quad 52 \%$ yield, $98 \%$ ee

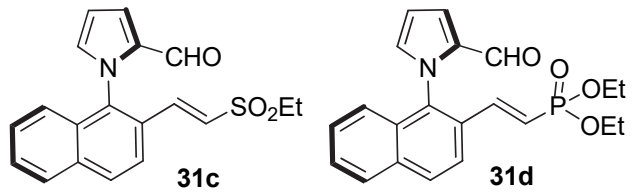

$50 \%$ yield, $94 \%$ ee $\quad 58 \%$ yield, $94 \%$ ee

(c) Synthetic applications<smiles>O=Cc1ccc2ccc3ccccc3c2c1-c1cccc2ccccc12</smiles>

27d

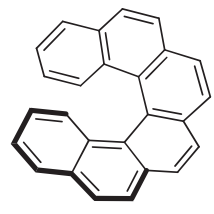

33

$87 \%$ yield, $96 \%$ ee<smiles>CCOC(=O)C=Cc1ccc2ccc3cccc4ccc1c2c34</smiles>

$42 \%$ yield, $96 \%$ ee<smiles>O=C(O)c1ccc2ccccc2c1-c1c(C(=O)O)ccc2ccc3ccccc3c12</smiles>

34

$82 \%$ yield, $96 \%$ ee<smiles>O=CC1=c2c3ccc(CO)c2=CC=CC(=C3c2cccc3ccccc23)C=C1</smiles>

$86 \%$ yield, $96 \%$ ee<smiles>Oc1ccc2ccccc2c1-c1c(O)ccc2ccc3ccccc3c12</smiles>

35

$51 \%$ yield, $96 \%$ ee

Scheme 8 Pd-catalyzed asymmetric electrochemical C-H olefinations

ylic acids have received extensive attention in recent decades due to the attractiveness of $\mathrm{CO}_{2}$ as a $\mathrm{C} 1$ synthon.

In $2014, \mathrm{Lu}$ and co-workers ${ }^{[37]}$ reported the first investigation of asymmetric electrocarboxylation of 1-phenylethyl chloride catalyzed by an electrogenerated chiral $\mathrm{Co}$ (salen) complex. 2-Phenylpropionic acid was afforded in 37\% yield and $83 \%$ ee (Scheme 9a). Although low yielding, this study laid the foundation for further research.

In 2018, Mei and co-workers ${ }^{[38]}$ reported the first Pd-catalyzed regioselective carboxylation of homostyrenyl acetates utilizing electric current as the reductant, and also demonstrated the first catalytic asymmetric carboxylation of cinnamyl acetate, which provided a heretofore unavailable means to construct chiral phenyl acetic acids from homostyrenyl acetates (Scheme 9b). The proposed mechanism for this Pd-catalyzed carboxylation reaction via electrochemical reduction is shown in Scheme 9c.

\subsection{Reductive asymmetric decarboxylation}

In 2002 Duñach and co-workers ${ }^{[39]}$ reported the electroreductive cleavage of the allyl group of allyl 2-methyl-1tetralone-2-carboxylate which afforded optically active 2-methyl-1-tetralone in low enantioselectivity in the presence of a chiral nickel-complex (Scheme 10). The reaction probably proceeded through the electrochemical generation of $\mathrm{Ni}(0)$ complex, which added oxidatively to the $\mathrm{C}-\mathrm{O}$ bond of the allyl ester group of $\mathbf{4 0}$ to form a $\pi$-allyl-Ni(II) complex. The formation of $\mathbf{4 1}$ and $\mathbf{4 2}$ could be the result of deallylation with or without decarboxylation, and 43 was formed from an intramolecular allyl transfer reaction to the carbonyl group.

\subsection{Reductive asymmetric couplings}

Transition metal-catalyzed reductive cross-coupling is a powerful strategy for the formation of carbon-carbon bonds. However, a superstoichiometric proportion of metal powder is often needed as a reductant for catalyst turnover. In 2019 Reisman and co-workers ${ }^{[40]}$ reported the first asymmetric electrochemical reductive cross-coupling of alkenyl bromides and benzyl chlorides with a nickel catalyst and chiral ligand L9. The reaction exhibited high efficiency, high enantioselectivity, and broad functional group tolerance (Scheme 11). 


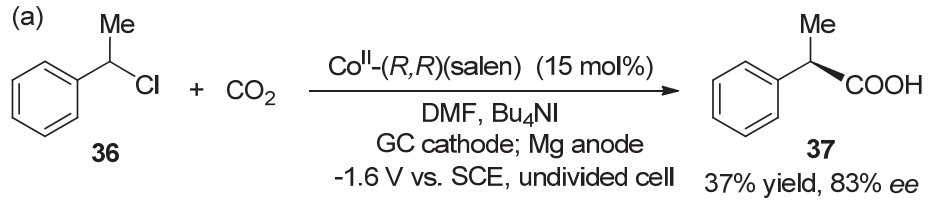

(b)
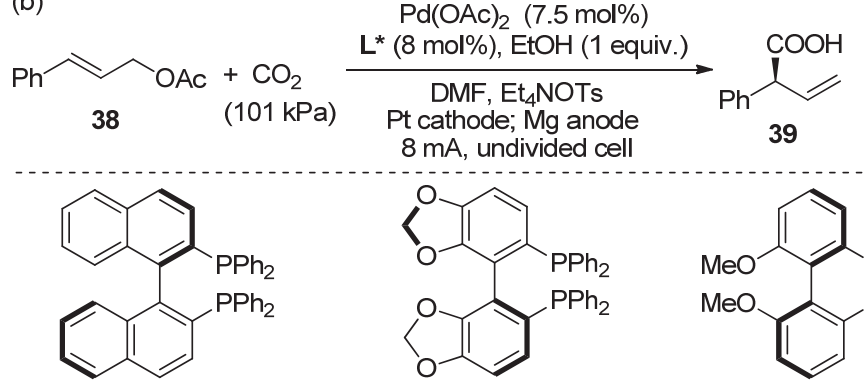

L5

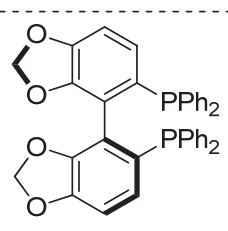

L6

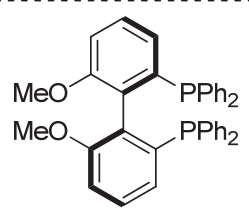

L7

$7: 1 \mathrm{~B} / \mathrm{L}, 59 \%$ yield, $56 \%$ ee $5: 1 \mathrm{~B} / \mathrm{L}, 55 \%$ yield, $61 \%$ ee $6: 1 \mathrm{~B} / \mathrm{L}, 66 \%$ yield, $67 \%$ ee

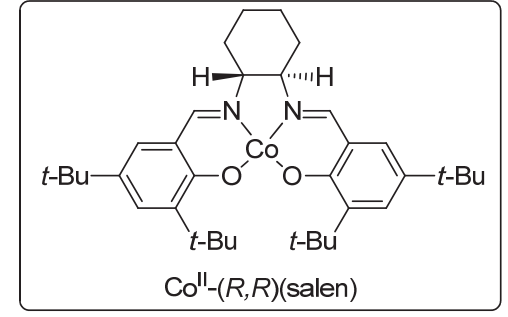

(c) A plausible mechanism

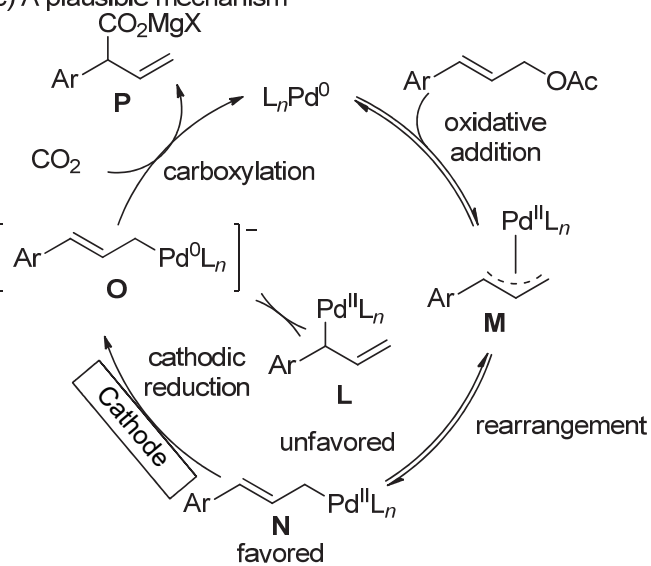

Scheme 9 Asymmetric organotransition metal-catalyzed electrocarboxylation

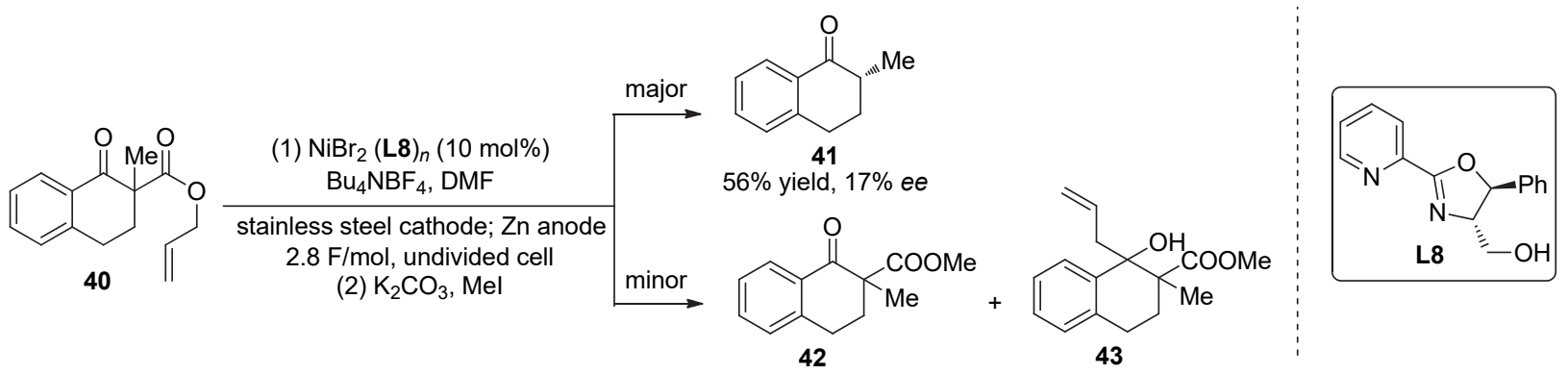

Scheme 10 Ni-catalyzed enantioselective electroreductive $\mathrm{C}-\mathrm{C}$ bond cleavage

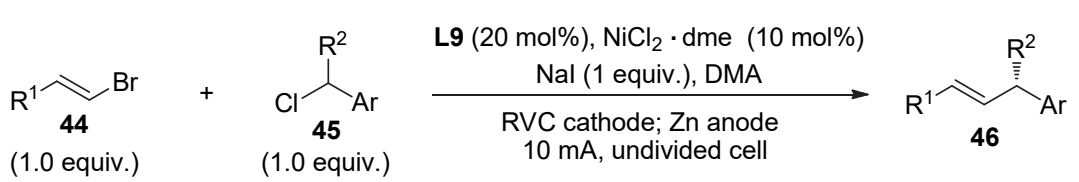

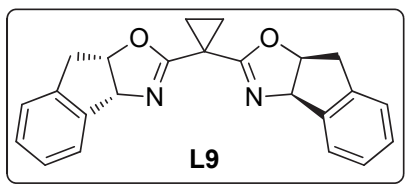<smiles>COc1ccc(/C=C/[C@H](C)c2ccccc2)cc1</smiles>

$84 \%$ yield, $94 \%$ ee<smiles>COc1cccc([C@H](C)/C=C/c2ccc(C)cc2)c1</smiles>

$82 \%$ yield, $92 \%$ ee<smiles>COc1ccc(/C=C/[C@H](C)c2ccccc2)cn1</smiles>

$78 \%$ yield, $93 \%$ ee

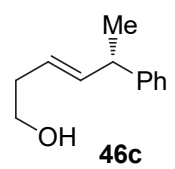

$56 \%$ yield, $93 \%$ ee<smiles>COc1cccc([C@H](C)/C=C\CCCl)c1</smiles>

$71 \%$ yield, $92 \%$ ee<smiles>COc1ccc(/C=C/[C@H](Cc2ccccc2)c2ccccc2)cc1</smiles>

$80 \%$ yield, $92 \%$ ee<smiles>COc1ccc(/C=C/[C@H]2CCc3ccccc32)cc1</smiles>

$84 \%$ yield, $94 \%$ ee<smiles>COc1ccc(/C=C/[C@H](C)c2ccccc2OC)cc1</smiles>

$73 \%$ yield, $90 \%$ ee

Scheme 11 Ni-catalyzed asymmetric electrochemical reductive cross-coupling

Very recently, Mei and co-workers ${ }^{[41]}$ reported the first example of a Ni-catalyzed enantioselective electrochemical reductive coupling of aryl bromides under very mild con- ditions. This process afforded axially chiral BINOL derivatives in good yield and enantiomeric excess (Scheme 12). Common metal reductants such as $\mathrm{Mn}$ or $\mathrm{Zn}$ powder re- 
sulted in significantly lower yields in the absence of electric current under otherwise identical conditions, which underscores the enhanced reactivity enabled by the combination of transition metal catalysis and electrochemistry.

\section{Conclusion and outlook}

This review summarized recent progress in asymmetric organotransition metal-catalyzed electrochemistry (AOM$\mathrm{CE}$ ). Chiral ligands combined with transition metals in the presence of electricity have been established for efficient enantioselective synthesis. Although AOMCE is readily understood, designed, and implemented, examples of
AOMCE are rare, some challenges still need to be addressed. For example, AOMCE methods limited to Os, Mn, $\mathrm{Cu}, \mathrm{Rh}, \mathrm{Co}, \mathrm{Pd}$, or Ni catalysis, thus the design of diversified catalysts is highly desired. Furthermore, free metal ions are prone to accept electrons from cathode to yield inert zero-valent metals, which result in poor yields or no reaction at all. We hope that this review provides helpful overview of the current state of AOMCE. We anticipate that the problems mentioned above will be solved in the near future after further investigation, and novel AOMCE methods will also be developed with some regularity.

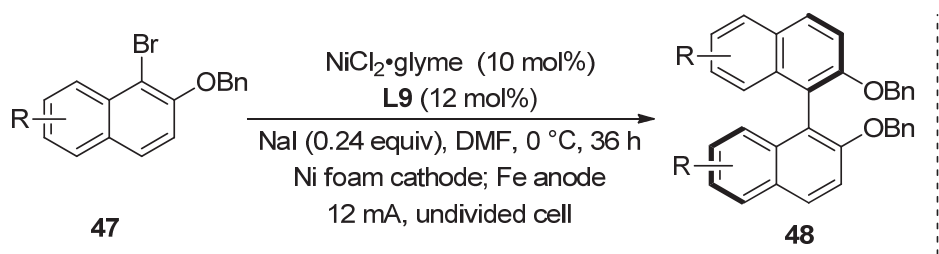

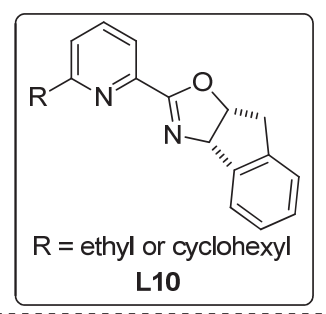

- Gram scale synthesis

- High yield and enantioselectivity

- Comparison with Mn powder

[A] electrochemistry, 10\% [Ni]

[B] Mn as the reductant, $10 \%$ [Ni]

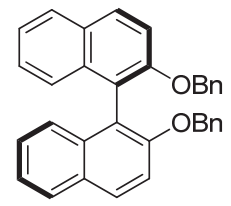

48a, $1.03 \mathrm{~g}$

[A] $88 \%$ yield, 95:5 er [B] 14\% yield, $94: 6$ er

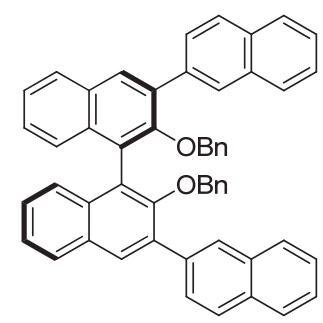

48f, $1.42 \mathrm{~g}$

[A] 79\% yield, 95.5:4.5 er [B] $20 \%$ yield, $94: 6$ er

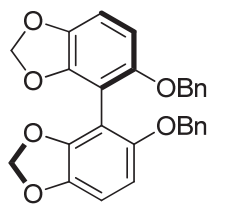

48b, $0.86 \mathrm{~g}$

[A] 75\% yield, 89:11 er [B] 17\% yield, 60:40 er

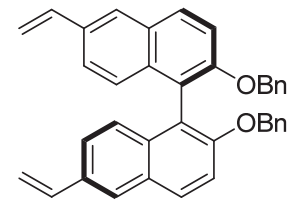

48c, $1.02 \mathrm{~g}$

[A] 79\% yield, 95:5 er [B] 10\% yield, 95:5 er<smiles>COCc1ccc2c(-c3c(OCc4ccccc4)ccc4ccc(COC)cc34)c(Cc3ccccc3)ccc2c1</smiles>

48d, $1.32 \mathrm{~g}$

[A] 86\% yield, 94:6 er [B] NR

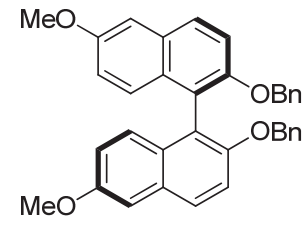

$48 \mathrm{e}, 1.12 \mathrm{~g}$

[A] $85 \%$ yield, $96: 4$ er [B] 6\% yield, 94:6 er<smiles>O=C(c1ccccc1)c1ccc2c(-c3ccc4cc(Cc5ccccc5)c(Cc5ccccc5)ccc3-4)c(OCc3ccccc3)ccc2c1</smiles>

$48 \mathrm{~g}, 1.44 \mathrm{~g}$

[A] 81\% yield, 95:5 er [B] 4\% yield, 94:6 er<smiles>Fc1cc(F)cc(-c2cc3ccccc3c(-c3c(OCc4ccccc4)c(-c4cc(F)cc(F)c4)cc4ccccc34)c2OCc2ccccc2)c1</smiles>

48h, $1.29 \mathrm{~g}$

[A] 76\% yield, 90:10 er [B] 15\% yield, $86: 14 \mathrm{er}$

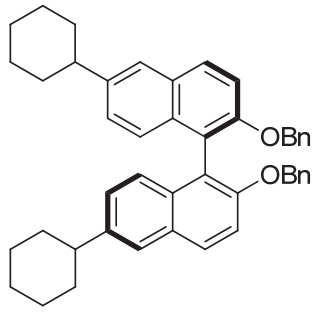

$48 \mathrm{i}, 1.24 \mathrm{~g}$

[A] $80 \%$ yield, $97: 3 \mathrm{er}$ [B] 11\% yield, 93:7 er

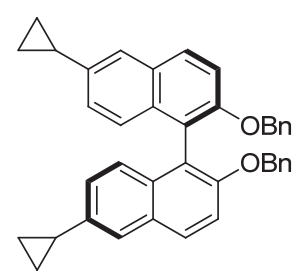

48j, $1.16 \mathrm{~g}$

[A] 85\% yield, 96:4 er [B] 12\% yield, $95: 5 \mathrm{er}$

Scheme 12 Ni-catalyzed asymmetric electrochemical reductive cross-coupling

\section{References}

[1] Kolbe, H. J. Prakt. Chem. 1847, 41, 137.

[2] Baizer, M. M. J. Electrochem. Soc. 1964, 111, 215.

[3] (a) Wang, F.; Stahl, S. S. Acc. Chem. Res. 2020, 53, 561.

(b) Siu, J. C.; Fu, N.; Lin, S. Acc. Chem. Res. 2020, 53, 547.

(c) Fuchigami, T.; Inagi, S. Acc. Chem. Res. 2020, 53, 322.

(d) Flexer, V.; Jourdin, L. Acc. Chem. Res. 2020, 53, 311.

(e) Jiao, K.-J.; Xing, Y.-K.; Yang, Q.-L.; Qiu, H.; Mei, T.-S. Acc.

Chem. Res. 2020, 53, 300

(f) Robinson, S.; Sigman, M. S. Acc. Chem. Res. 2020, 53, 289.

(g) Jing, Q.; Moeller, K. D. Acc. Chem. Res. 2020, 53, 135

(h) Leech, M. C.; Lam, K. Acc. Chem. Res. 2020, 53, 121.

(i) Yamamoto, K.; Kuriyama, M.; Onomura, O. Acc. Chem. Res. 2020, 53, 105.

(j) Ackermann, L. Acc. Chem. Res. 2020, 53, 84.

(k) Kingston, C.; Palkowitz, M. D.; Takahira, Y.; Vantourout, J. C.;
Peters, B. K.; Kawamata, Y.; Baran, P. S. Acc. Chem. Soc. 2020, 53, 72.

(1) Röckl, J. L.; Pollok, D.; Franke, R.; Waldvogel, S. R. Acc. Chem. Res. 2020, 53, 45.

(m) Xiong, P.; Xu, H.-C. Acc. Chem. Res. 2019, 52, 3339.

(n) Yuan, Y.; Lei, A. Acc. Chem. Res. 2019, 52, 3309.

(o) Jiang, Y.; Xu, K.; Zeng, C. Chem. Rev. 2018, $118,4485$.

(p) Yang, Q.-L.; Fang, P.; Mei, T.-S. Chin. J. Chem. 2018, 36, 338.

(q) Ma, C.; Fang, P.; Mei, T.-S. ACS Catal. 2018, 8, 7179.

(r) Karkas, M. D. Chem. Soc. Rev. 2018, 47, 5786.

(s) Horn, E. J.; Rosen, B. R.; Baran, P. S. ACS Cent. Sci. 2016, 2, 302.

[4] (a) Hou, Z.-W.; Xu, H.-C. Chin. J. Chem. 2020, 38, 394.

(b) Ye, Z.; Zhang, F. Chin. J. Org. Chem. 2020, 40, 241 (in Chinese).

(叶增辉, 张逢质, 有机化学, 2020, 40, 241.)

(c) Qian, X.-Y.; Xiong, P.; Xu, H.-C. Acta Chim. Sinica 2019, 77, 
879 (in Chinese).

(钱向阳, 熊鹏, 徐海超, 化学学报, 2019, 77, 879.)

(d) Yang, Q.-L.; Wang, X.-Y.; Weng, X.-J.; Yang, X.; Xu, X.-T.; Tong, X.; Fang, P.; Wu, X.-Y.; Mei, T.-S. Acta Chim. Sinica 2019, 77, 866 (in Chinese).

(杨启亮, 王向阳, 翁信军, 杨祥, 徐学涛, 童晓峰, 方萍, 伍新 燕, 梅天胜, 化学学报, 2019, 77, 866.)

(e) Zhang, H. Tang, R.; Shi, X.; Xie, L.; Wu, J. Chin. J. Org. Chem. 2019, 39, 1837 (in Chinese).

(张怀远, 唐蓉萍, 石星丽, 颉林, 伍家卫, 有机化学, 2019, 39, 1837.)

(f) Feng, E.-Q.; Hou, Z.-W.; Xu, H.-C. Chin. J. Org. Chem. 2019 , 39, 1424 (in Chinese)

(冯恩祺，侯中伟，徐海超，有机化学, 2019, 39, 1424.)

(g) Zhou, Z.; Yuan, Y.; Cao, Y.; Qiao, J.; Yao, A.; Zhao, J.; Zou, W. Chen, W.; Lei, A. Chin. J. Chem. 2019, 37, 611.

(h) Lu, F.; Yang, Z.; Wang, T.; Wang, T.; Zhang, Y.; Yuan, Y.; Lei, A. Chin. J. Chem. 2019, 37, 547 .

(i) Hou, Z.-W.; Yan, H.; Song, J.; Xu, H.-C. Chin. J. Chem. 2018, 36,909 .

(j) Wu, Y.; Xi, Y.; Zhao, M.; Wang, S. Chin. J. Org. Chem. 2018, 38, 2590 (in Chinese).

(吴亚星，席亚超，赵明，王思懿，有机化学，2018，38，2590.)

[5] (a) Chang, X.; Zhang, Q.; Guo, C. Angew. Chem., Int. Ed. 2020, 59, 12612 .

(b) Ghosh, M.; Shinde, V. S.; Rueping, M. Beilstein J. Org. Chem. 2019, 15, 2710.

(c) Lin, Q.; Li, L.; Luo, S. Chem. Eur. J. 2019, 25, 10033.

[6] Seebach, D.; Oei, H. A. Angew. Chem., Int. Ed. 1975, 14, 634.

[7] (a) Louafi, F.; Moreau, J.; Shahane, S.; Golhen, S.; Roisnel, T.; Sinbandhit, S.; Hurvois, J.-P. J. Org. Chem. 2011, 76, 9720.

(b) Feroci, M.; Inesi, A.; Orsini, M.; Palombi, L. Org. Lett. 2002, 4, 2617.

[8] (a) Kodama, Y.; Fujiwara, A.; Kawamoto, H.; Ohta, N.; Kitani, A.; lto, S. Chem. Lett. 2001, 30, 240.

(b) Horner, L.; Degner, D. Tetrahedron Lett. 1971, 12, 1241.

[9] (a) Shiigi, H.; Mori, H.; Tanaka, T.; Demizu, Y.; Onomura, O. Tetrahedron Lett. 2008, 49, 5247.

(b) Kuroboshi, M.; Yoshihisa, H.; Cortona, M. N.; Kawakami, Y.; Gao, Z.; Tanaka, H. Tetrahedron Lett. 2000, 41, 8131.

(c) Kashiwagi, Y.; Kurashima, F.; Kikuchi, C.; Anzai, J.; Osa, T.; Bobbitt, J. M. Chem. Commun. 1999, 1983.

[10] (a) Kashiwagi, Y.; Kurashima, F.; Chiba, S.; Anzai, J.; Osa, T.; Bobbitt, J. M. Chem. Commun. 2003, 114.

(b) Moutet, J. C.; Duboc-Toia, C.; Ménage, S.; Tingry, S. Adv. Mater. 1998, 10, 665 .

(c) Komori, T.; Nonaka, T. J. Am. Chem. Soc. 1984, 106, 2656.

(d) Firth, B. E.; Miller, L. L. J. Am. Chem. Soc. 1976, 98, 8272.

(e) Watkins, B. F.; Behling, J. R.; Kariv, E.; Miller, L. L. J. Am. Chem. Soc. 1975, 97, 3549.

[11] Gourley, R. N.; Grimshaw, J.; Millar, P. G. Chem. Commun. 1967, 1278.

[12] (a) Kobayashi, S.; Sugiura, M. Adv. Synth. Catal. 2006, 348, 1496. (b) Lohray, B. B. Tetrahedron: Asymmetry 1992, 3, 1317.

[13] (a) Sugimoto, H.; Kitayama, K.; Mori, S.; Itoh, S. J. Am. Chem. Soc. 2012, 134, 19270.

(b) Metin, O.; Alp, N. A.; Akbayrak, S.; Bicer, A.; Gultekin, M. S.; Ozkar, S.; Bozkaya, U. Green Chem. 2012, 14, 1488

(c) Sugimoto, H.; Kitayama, K.; Mori, S.; Itoh, S. J. Am. Chem. Soc. 2012, 134, 19270.

[14] (a) Sharpless, K. B. Angew. Chem., Int. Ed. 2002, 41, 2024.

(b) Kolb, H. C.; VanNieuwenhze, M. S.; Sharpless, K. B. Chem. Rev. 1994, 94, 2483.

(c) Katsuki, T.; Sharpless, K. B. J. Am. Chem. Soc. 1980, 102, 5974.

[15] Amundsen, R.; Balko, E. N. Appl. J. Electrochem. 1992, 22, 810.

[16] Torii, S.; Liu, P.; Tanaka, H. Chem. Lett. 1995, 24, 319.
[17] Torii, S.; Liu, P.; Bhuvaneswari, N.; Amatore, C.; Jutand, A. J. Org. Chem. 1996, 61, 3055.

[18] Noyori, R. Asymmetric Catalysis in Organic Synthesis, Wiley, New York, 1994.

[19] Guo, P.; Wong, K.-Y. Electrochem. Commun. 1999, 1, 559.

[20] Tanaka, H.; Kuroboshi, M.; Takeda, H.; Kanda, H.; Torii, S. J. Electroanal. Chem. 2001, 507, 75 .

[21] Fu, N.; Song, L.; Liu, J.; Shen, Y.; Siu, J. C.; Lin, S. J. Am. Chem. Soc. 2019, 141, 14480.

[22] Minato, D.; Arimoto, H.; Nagasue, Y.; Demizu, Y.; Onomura, O. Tetrahedron. 2008, 64, 6675.

[23] Onomura, O.; Arimoto, H.; Matsumura, Y.; Demizu, Y. Tetrahedron Lett. 2007, 48, 8668.

[24] Shono, T.; Hamaguchi, H.; Matsumura, Y. J. Am. Chem. Soc. 1975, $97,4264$.

[25] (a) Jones, A. M.; Banks, C. E. Beilstein J. Org. Chem. 2014, 10, 3056.

(b) Onomura, O. Heterocycles 2012, 85, 2111

(c) Shono, T. Top. Curr. Chem. 1988, 148, 1.

[26] Yan, M.; Kawamata, Y.; Baran, P. S. Chem. Rev. 2017, 117, 13230.

[27] (a) D'Oca, M. G. M.; Pilli, R. A.; Pardini, V. L.; Curi, D.; Comninos, F. C. M. J. Braz. Chem. Soc. 2001, 12, 507.

(b) Sierecki, E.; Errasti, G.; Martens, T.; Royer, J. Tetrahedron 2010, 66, 10002 .

(c) Lee, D.-S. Tetrahedron: Asymmetry 2009, 20, 2014.

(d) Shankaraiah, N.; Pilli, R. A.; Santos, L. S. Tetrahedron Lett. 2008, 5098.

(e) Zelgert, M.; Nieger, M.; Lennartz, M.; Steckhan, E. Tetrahedron 2002, 58, 2641.

(f) Matsumura, Y.; Kanda, Y.; Shirai, K.; Onomura, O.; Maki, T. Tetrahedron 2000, 56, 7411.

[28] Fu, N.; Li, L.; Yang, Q.; Luo, S. Org. Lett. 2017, 19, 2122.

[29] Gao, P.-S.; Weng, X.-J.; Wang, Z.-H.; Zheng, C.; Sun, B.; Chen, Z.-H.; You, S.-L.; Mei, T.-S. Angew. Chem., Int. Ed. 2020, 59, 15254 .

[30] (a) Lennox, A. J. J.; Geos, S. L.; Webster, M. P.; Koolman, H. F.; Djuric, S. W.; Stahl, S. S. J. Am. Chem. Soc. 2018, 140, 11227.

(b) Wang, F.; Rafiee, M.; Stahl, S. S. Angew. Chem., Int. Ed. 2018, $57,6686$.

(c) Wu, Y.; Yi, H.; Lei, A. ACS Catal. 2018, 8, 1192.

(d) Li, C.; Zeng, C.-C.; Hu, L.-M.; Yang, F.-L.; Yoo, S. J.; Little, R. D. Electrochim. Acta 2013, 114, 560.

(e) Cao, Y.; Suzuki, K.; Tajima, T.; Fuchigami, T. Tetrahedron 2005, 6854.

[31] Ryan, M. C.; Whitemire, L. D.; Mccann, S. D.; Stahl, S. S. Inorg. Chem. 2019, 58, 10194.

[32] Badalyan, A.; Stahl, S. S. Nature 2016, 535, 406.

[33] Huang, X.; Zhang, Q.; Lin, J.; Harms, K.; Meggers, E. Nat. Catal. 2019, 2, 34 .

[34] Zhang, Q.; Chang, X.; Peng, L.; Guo, C. Angew. Chem., Int. Ed. 2019, 58, 6999.

[35] Lu, P.; Jackson, J. J.; Eickhoff, J. A.; Zakarian, A. J. Am. Chem. Soc. 2015, 137, 656.

[36] Dhawa, U.; Tian, C.; Wdowik, T.; Oliveira, J. C. A.; Hao, J.; Ackermann, L. Angew. Chem., Int. Ed. 2020, 59, 13451.

[37] Chen, B.-L.; Zhu, H.-W.; Xiao, Y.; Sun, Q.-L.; Wang, H.; Lu, J.-X Electrochem. Commun. 2014, 42, 55.

[38] Jiao, K.-J.; Li, Z.-M.; Xu, X.-T.; Zhang, L.-P.; Li, Y.-Q.; Zhang, K.; Mei, T.-S. Org. Chem. Front. 2018, 5, 2244.

[39] Franco, D.; Riahi, A.; Hénin, F.; Muzart, J.; Duñach, E. Eur. J. Org. Chem. 2002, 2257.

[40] DeLano, T. J.; Reisman, S. E. ACS Catal. 2019, 9, 6751

[41] Qiu, H.; Shuai, B.; Wang, Y.-Z.; Liu, D.; Chen, Y.-G.; Gao, P.-S.; Ma, H.-X.; Chen, S.; Mei, T.-S. J. Am. Chem. Soc. 2020, 142, 9872. 